in this journal. Vol. 4, "Cycles of Reduced Ideals in Quadratic Fields", prepared by Dr. E. L. Ince, was published in August, and vol. 5, containing the prime factors of all numbers from 1 to 100,000 , is now in the press, and it should be available before the end of the year. This valuable set of tables is not as well known as it should be, possibly because it has not been handled by a publishing firm. New arrangements have now been made, and in future the tables will be sold by the Cambridge University Press.

\section{Seismological Committee of the British Association}

THE thirty-ninth report of this Committee is chiefly concerned with the maintenance of the International Seismological Summary. The University of Oxford has agreed to provide room and part of the working expenses until the time comes when these can be met entirely from sources outside the University, such as the International Union for Geodesy and Geophysies, the Crombie and Gray-Milne funds, and the British Association grants. The summary for the third quarter of 1930 is now in course of preparation, and in this the Committee is able to avail itself of the new Jeffreys-Bullen tables, the accuracy of which will greatly help in the determination of epicentres. The precision of the work now being carried on is evident from the suggestion that the time is approaching when the spheroidal form of the earth will have to be taken into account in the estimation of distances.

\section{International Physiological Congress}

THE Fifteenth International Physiological Congress will be held in Leningrad and Moscow on August 9-17, 1935, under the presidency of Prof. I. P. Pavlov. Arrangements will be made for visits, after the Congress, to various parts of Russia. The International Committee consists of Profs. Bottazzi, Frank, A. V. Hill, Howell, Johansson, Lapicque, Pavlov and the Congress Committee of Profs. Pavlov (president), Orbeli, Palladin, Beritoff (vicepresidents), Fedorov (general secretary), Volborth, Koshtojanz (secretaries). It will greatly assist the work of the Committee if physiologists intending to be present enrol as early as possible. Correspondence concerning the Congress should be addressed to Leningrad, Main P.O., Box 13.

\section{Iron and Steel Institute}

AT the general meeting of the Iron and Steel Institute in Brussels which opened on September 10, it was announced that H.M. the King of the Belgians, Leopold III, has honoured the Institute by accepting nomination as honorary member. This continues the tradition by which H.M. King Leopold II (1874-1909) and H.M. King Albert I (1913-1934) had been honorary members of the Institute. The Council is proposing Sir Harold Carpenter for election as president at the annual meeting of the Institute in May 1935, and Mr. James Henderson, deputy chairman and general manager of the Appleby Iron Company, Ltd., and of the Frodingham Iron and Steel Company, Ltd., and president of the British Iron and Steel Federation, has been elected honorary treasurer in succession to Sir Harold Carpenter, who is resigning at the end of September. The date of the annual meeting for 1935 will be May 1-3.

\section{Announcements}

THE following gold medals of the North East Coast Institution of Engineers and Shipbuilders have recently been awarded: Engineering Gold Medal to W. T. Bottomley, E. W. Corlett and Frank Piercy for their paper entitled "The Possibilities of Applying Improve. ments Effected in Modern Land Power Plant to Ship Propelling Machinery"; Shipbuilding Gold Medal to N. M. Hunter for his paper entitled "The ElectricWelded Ship Peter G. Campbell".

THE second meeting of the Microchemical Club will be held at Reading on September 29. At 11 p.m. the Club will meet at the University for the discussion of papers, and after luncheon a visit will be paid to the National Institute for Research in Dairying, Shinfield, where demonstrations will be given.

DURING the forthcoming winter it will be passible for Mr. H. V. Garner, the guide demonstrator of the Rothamsted Experimental Station, Harpenden, and other members of the staff, to give lectures to chambers of agriculture and horticulture, farmers' clubs, farm workers' associations, agricultural societies, etc., on the Rothamsted experiments. All communications regarding lectures should be addressed to the Secretary, Rothamsted Experimental Station, Harpenden, Herts.

A CONFERENCE of malting barley growers and malting barley buyers and maltsters will be held at the Rothamsted Experimental Station on October 10, at 11.30 a.m., when the chair will be taken by Mr. Stanley O. Ratcliff, president of the National Farmers' Union. The purpose of the conference is to enable buyers and maltsters to meet growers and discuss with them the grading of samples. Further information can be obtained from the Secretary, Rothamsted Experimental Station, Harpenden.

ApPLications are invited for the following appointments, on or before the dates mentioned :-A demonstrator in applied mechanies at the Royal Naval College, Greenwich-The Adviser on Education, Admiralty, Whitehall, S.W.1 (Sept. 17). Veterinary officers for the Administrative Counties of East and West Suffolk-The Clerk of the Local Authority, County Hall, Ipswich (Sept. 20). Civilian garrison engineers for the Establishment for Engineer Services at Army stations in Great Britain and Northern Ireland-The Under-Secretary of State (C. 5), The War Office, London, S.W.1 (Sept. 22). A lecturer in power plant at the Polytechnic, Regent Street, London, W.1-The Director of Education (Sept. 24). A botanical specialist and an animal breeding specialist in the Fouad I Agricultural Museum, Egypt-The Under Secretary of State, Ministry of Agriculture, Cairo (Sept. 30). A lecturer in physiology at the University of Cape Town-The Secretary, Office of the High Commissioner for the Union of South Africa, Trafalgar Square, London (Oct. 17). 